\title{
ANALISIS FAKTOR - FAKTOR YANG MEMPENGARUHI KONSUMEN DALAM MENGAMBIL KEPUTUSAN PEMBELIAN PRODUK ( STUDI KASUS PADA INDUSTRI TAHU DADI JAYA DI BOYOLALI TAHUN 2020 )
}

\author{
Citra Puspita Sari ${ }^{1)}$, Dasmadi ${ }^{2)}$, dan Listyowati Puji $\mathbf{R}^{3)}$ \\ Fakultas Ekonomi Manajemen \\ Universitas Boyolali \\ Jl. Pandanaran 405, Telp. 0276321328 Boyolali \\ e-mail: citratata94@gmail.com ${ }^{1)}$, dasmadi82@gmail.com ${ }^{2)}$, listyowatipujirahayu63@gmail.com ${ }^{3)}$
}

\begin{abstract}
ABSTRAK
Penelitian ini mengetahui pengaruh variabel harga, produk, promosi dan tempat terhadap keputusan pembelian produk Tahu Dadi Jaya di Boyolali. Penelitian ini menggunakan data pustaka dan teknik pengumpulan data melalui kuesioner serta memakai metode kuantitatif. Sampel dalam data ini ialah 100 Orang konsumen dengan menggunakan metode sampel jenuh, di Tahu Dadi jaya di Boyolali. Uji regresi linier berganda dengan menggunakan SPSS 22. Dan seterusnya akan dilihat, seberapa besar pegaruh variabel promosi ( X1 ), produk ( X2 ), harga ( X3 ) dan tempat ( X4 ) yang akan mempengaruhi keputusan pembelian pada pengujian hipotesis. Seterusnya hasil uji regresi linear berganda (RSquare) didapatkan nilai Adjusted R Square sebesar 14,7\%. Dapat dijelaskan bahwa $14,7 \%$ variabel tersebut mempengaruhi keputusan pembelian. Sedang selisihnya 85,3\%, dipengaruhi oleh variabel lain yaitu : bonus,potongan harga dan lain - lain.Hasil penelitian ini bahwa variabel keputusan pembelian mampu dijelaskan oleh variabel harga dengan menggunakan hasil dari uji parsial (Uji t) berpengaruh signifikan terhadap variabel keputusan pembelian produk yang terjadi pada Tahu Dadi Jaya di Boyolali.
\end{abstract}

Kata kunci : harga, keputusan pembelian, produk, promosi, tempat

\section{ABSTRACT}

This study investigates the effect of price, product, promotion and place variables on purchasing decisions of Tahu Dadi Jaya products in Boyolali. This study uses library data and data collection techniques through questionnaires and uses quantitative methods. The sample in this data is 100 consumers using the saturated sample method, in Tahu Dadi Jaya in Boyolali. Multiple linear regression test using SPSS 22. And so on, it will be seen, how much influence the promotion variable $(X 1)$, product (X2), price (X3) and place (X4) will influence purchasing decisions on hypothesis testing. Then the results of multiple linear regression (RSquare) obtained the Adjusted $R$ Square value of $14.7 \%$. It can be explained that $14.7 \%$ of these variables influence purchasing decisions. While the difference is $85.3 \%$, it is influenced by other variables, namely: bonuses, discounted prices and others .The results of this study indicate that the purchasing decision variable can be explained by the price variable using the results of the partial test ( $t$ test) which has a significant effect on the product purchasing decision variable that occurs in Tahu Dadi Jaya in Boyolali.

Keywords: price, purchase decision, product, promotion, place 


\section{Pendahuluan}

Pengguna produk tahu dan tempe sebagai makanan di Indonesia luar biasa tingginya. Beralaskan data dari Badan Pusat Statistik Nasional bahwa konsumsi tahu mengarahlebih tinggi dibandingkan dengan tempe. Peristiwa tersebut dilihat dalam kurun waktu 5 tahun terakhir bahwa konsumsi produk tahu dari tahun ketahun cenderung meningkat yaitu konsumsi rata-rata sebesar $1,85 \%$ sedangkan produk tempe rata - rata semakin menurun sebesar -2,64\% ( BPS, 2015 ). Tinggi rendahnya pengguna produk tahu dan tempe akan berakibat pada kemajuan industri pengolahan kedelai di Indonesia. Semakin tinggi angka konsumsi terhadap produk hasil pengolahan kedelaimaka memberikan peluang lebih bagi produsen tahu dan tempe untuk menjajakan produk tersebut. sebagai produsen tahu seharusnya lebih mengutamakan kepuasan konsumen baik dari segi pelayanan maupun atribut produk agar produk tahu dapat berkembang pesat di pasar yang akan berdampak pada kapasitas penjualan yang akan berdampak pada tujuan utama perusahaan dalam mencapai keuntungan semaksimal mungkin dapat menentukan strategi pemasaran dan segmentasinya.

Manajemen pemasaran yaitu pasar sasaran yang dapat meraih guna mempertahankan serta menumbuhkan pelanggan dengan menciptakan serta menghantarkan dan mengomunikasikan nilai pelanggan tersebut Menurut Kotler dan Keller ( $2011: 6$ ). Setiap produsen harus memikirkan kegiatan pemasaran produk jauh sebelum produk tersebut dihasilkan sampai dikomsumsi oleh konsumen akhir.

Menurut Kotler dan Armstrong ( $2014: 253$ ) "Product quality is the characteristic of a product or service that bear on its ability to satisfy stated or 16 implied customer needs" diartikan dalam Bahasa Indonesia: "kualitas produk adalah karakter yang dimiliki sebuah produk yang mempunyai kemampuan untuk memenuhi kebutuhan pelanggan". Sedangkan Menurut Kotler dan Armstrong ( 2012 :283 ) dalam Kresnamurti ( 2012: 3 ) "kualitas produk adalah kemampuan sebuah produk dalam memperagakan fungsinya, hal itu termasuk keseluruhan ketepatan, kemudahan, durabilitas, reliabilitas, pengoperasian dan reparasi produk juga atribut produk lainnya".

Lokasi mengacu berbagai aktivitas pemasaran untuk memperlancar dan mempermudah penyampaian atau penyaluran suatu barang dan jasa dari produsen kepada konsumen menurut Tjiptono ( $2015: 345$ ). Menurut Kotler dan Amstrong ( $2014: 76$ ) "place include company activities that make the product available to target consumers".

Promosi merupakan variabel dalam bauran pemasaran yang sangat penting dilaksanakan oleh perusahaan dalam memasarkan produk dan jasa. Buchari Alma ( $2013: 181$ ) menyatakan promosi adalah komunikasi yang memberi penjelasan meyakinkan calon konsumen tentang barang dan jasa serta kegiatan promosi bukan hanya berfungsi sebagai alat komunikasi antara perusahaan dengan konsumen melainkan juga untuk mempengaruhi konsumen dalam kegiatan pembelian dan penggunaan jasa dengan keinginan serta kebutuhannya.

Keputusan pembelian adalah tindakan konsumen untuk membeli suatu produk barang ataupun jasa. "Customer buyer behavior refers to the buying behavior of final consumers-individuals and households that buy goods and services for personal consumption" Menurut Kotler dan Amstrong ( 2014 : 158 )". Keputusan pembelian tidak dapat terpisahkan dari bagaimana sifat seorang konsumen ( consumer behavior) sehingga masing - masing konsumen memiliki kebiasaan yang berbeda dalam melakukan pembelian.

Menurut Philip Kotler ( 2012 : 132 ) Harga merupakan sejumlah uang yang harus dibayar pelanggan untuk produk yang diinginkan. Menurut definisi diatas, kebijakan mengenai harga sifat hanya sementara berarti produsen harus mengikuti perkembangan harga dipasar dan harus mengetahui posisi perusahaan dalam situasi pasar secara keseluruhan. Harga merupakan faktor persaingan dalam memasarkan produk, Setiap perusahaan berlomba - lomba menawarkan harga yang menarik agar konsumen mau membeli produk yang ditawarkan. 
Industri tahu Dadi jaya satu-satunya industri perorangan yang berada di desa ketaon, selain itu sudah banyak pelanggan yang mempercayakan produk tahu Dadi jaya tersebut. Dari pengakuan masyarakat sekitar dari segi ukuran tahu tersebut memiliki ukuran yang besar. Limbah cairnya yang dihasilkan dari pengolahan tersebut dapat dimanfaat oleh masyarakat sekitar salah satunya biogas untuk limbah padat selain berfungsi buat makanan peliharaan bisa diolah menjadi tempe gembus.Sehingga berdasarkan latar belakang tersebut peneliti ingin mengetahui tentang kajian yang berupa pengaruh variabel - variabel promosi (X1), produk (X2), harga (X3) dan tempat (X4) berpengaruh secara simultan dan parsial terhadap keputusan pembelian. Dengan adanya penelitian ini, tujuan dari kajian tersebut ialah untuk mengetahui dari dampak dari variabel diatas secara parsial dan simultan berdasarkan hasil yang telah dikaji. Adapun beberapa manfaat penelitiannya yaitu mampu memberikan sumbangan pemikiran bagi banyak pihak terkait strategi pemasaran untuk suatu keputusan pembelian tentang suatu produk umkm.

\section{Landasan Teori dan Pengembangan Hipotesis}

\subsection{Manajemen Pemasaran}

Menurut Tjiptono ( 2012 : 2)manajemen pemasaran merupakan langkah - langkah aktivitas bisnis yang memperimbangkan untuk mempersiapkan, menentukan harga dan menyalurkan produk jasa serta ide yang mampu mencukupi dalam keinginan pasar sasaran dalam rangka mencapai tujuan organisasional. Manajemen pemasaran adalah suatu proses yang dilakukan untuk menganalisis, merencanakan, mengkoordinasi program - program yang menguntungkan perusahaan dan juga diartikan sebagai ilmu memilih pangsa pasar supaya dapat menciptakan nilai pelanggan yang unggul. Manajemen pemasaran yaitu pasar sasaran yang dapat meraih guna mempertahankan serta menumbuhkan pelanggan dengan menciptakan serta menghantarkan dan mengomunikasikan nilai pelanggan tersebut Menurut Kotler dan Keller ( 2011:6 ).

\subsection{Bauran Pemasaran}

Bauran pemasaran yang berada dalam suatu perusahaan dapat mempengaruhi respon sasarannya serta bauran pemasaran adalah pemasaran yang digunakan suatu perusahaan untuk terus mencapai tujuan pemasaran di pasar sasaran tersebut.Menurut Kotler ( 2012 : 101 ) marketing mixyang berpengaruh dalam suatu perusahaan dapat mempengaruhi respon sasarannya serta bauran pemasaran adalah pemasaran yang digunakan suatu perusahaan untuk mencapai target pemasaran di pasar sasaran.Perusahaan harus meraih strategi pemasaran agar perusahaan tersebut dapat bertahanuntuk menarik strategi pemasaran yang efektif diperlukan elemen - elemen bauran pemasaran. Bauran pemasaran pada suatu perusahaan dapat berdampak pada konsumen dan memperoleh respon dari konsumen terhadap barang atau jasa yang ditawarkan oleh perusahaan.

\subsection{Produk}

Perkembangan sebuah program dalam mencapai pasar yang diinginkan suatu perusahaan harus memulai dengan produk atau jasa yang dirancang guna memuaskan keinginan konsumen. Maka suatu perusahaan harus berusaha mengambil hati para konsumen untuk memperlancar jalannya produksi tersebut. Seorang Konsumen biasanya menginginkan suatu produk yang dapat membuat hati para konsumen puas serta mempunyai produk yang berkualitas. Menurut Kotler dan Armstrong (2014:253) Seorang Konsumen biasanya menginginkan suatu produk yang dapat membuat hati para konsumen puas serta mempunyai produk yang bermutu.Kemajuan sebuah program dalam mencapai pasar yang diinginkan suatu perusahaan harus mengambil langkah melalui produk atau jasa yang dirancang guna memuaskan keinginan konsumen hingga suatu perusahaan harus berusaha mengambil hati para konsumen untuk memperlancar jalannya produksi. Seorang Konsumen kebanyakan menginginkan suatu produk yang dapat membuat hati para konsumen puas serta mempunyai produk yang berkualitas. 
Tiap produk memiliki ciri masing-masing dan hal itulah yang menjadikan suatu produk terlihat unik dan berbeda dari yang lain. Produk dapat menjadi beberapa kelompok yaitu berdasarkan wujudnya, berdasarkan aspek daya tahan produk dan berdasarkan kegunaannya. Menurut Kotler dan Keller ( 2016 : 391 ) klasifikasi suatu produk diantaranya yaitu :

\section{Klasifikasi Produk Berdasarkan Daya Tahannya}

a. Nondurable goods ( Barang tidak tahan lama )

Adalah barang yang berwujud biasanya dikonsumsi dalam satu atau beberapa kegunaan serta tidak bertahan lama.

b. Durable goods ( Barang tahan lama )

Adalah barang nyata yang biasanya bertahan lama serta dapat digunakan seperti lemari es,peralatan mesin, dan pakaian.

\subsection{Harga}

Harga sering kali di kaitkan dengan kualitas konsumen cenderung untuk menggunakan harga sebagai indikator kualitas atau kepuasan potensial dari suatu produk. Harga tidak hanya sekedar angka pada label atau barang. Sepanjang sejarah pada umumnya harga ditetepkan melalui negosiasi antara penjual dan pembeli. Secara tradisional, harga telah diperlakukan sebagai penentu utama pilihan pembelian..Walaupun factor - faktor non harga telah makin berperan penting selama beberapa dasawarsa belakangan ini, harga merupakan unsur terpenting dalam menentukan pangsa pasar dan profitabilitas penetapan harga akan menjadi sangat penting terutama pada persaingan yang semakin ketat dan perkembangan permintaan yang terbatas. Peranan harga sangat penting untuk menjaga dan meningkatkan posisi perusahaan di pasar disamping itu untuk meningkatkan penjualan yang dapat meningkatkan keuntungan suatu perusahaan. penetapan harga yang mempengaruhi konsumen dengan sejumlah uang yang dibebankan atas suatu barang, jasa atau jumlah dari nilai uang yang ditukar oleh konsumen atas manfaat - manfaat yang dimiliki guna untuk menggunakan produk atau jasa Menurut Kotler dan Armstrong ( $2013: 151$ ).

Menurut Alma ( 2011 : 169 ) harga adalah dasar finansial atau ukuran lainnyatermasuk barang dan jasayang ditukarkan agar memperoleh hak kepemilikan atau penggunaan suatu barang dan jasa sehingga memicu kepuasan konsumen.Menurut Assauri (2014:223 ) harga adalah unsur yang menciptakanpenghasilan penjualan sedangkan unsur lainnya hanya unsur biaya saja.Berdasarkan kesimpulannyaharga adalah beberapa uang yang ditanggung jawabkan atas suatu produk yang ditukar konsumen atas nama baik yang dimiliki produk tersebut

\subsection{Tempat}

Lokasi adalah faktor situasional yang berdampak pada keputusan pembelian ketika suatu konsep pemasaran yang terdapat istilah yang dikenal dengan marketing mix yang terdiri dari produk, harga, lokasi dan promosi. Lokasi mengacu berbagai kegiatan pemasaran untuk memperlancar dan mempermudah penyampaian atau penyaluran suatu barang dan jasa dari produsen kepada konsumen menurut Tjiptono ( $2015: 345$ ). Menurut Kotler dan Amstrong ( $2014: 76$ ) "place include company activities that make the product available to target consumers". Area yang mampu untuk menumbuhkan dari segi ekonomi sehingga dapat mempertahankan kelangsungan hidup baik dalam suatu usaha perdagang ecer ataupun lainnya. Menurut Lupiyoadi dan Hamdani (2011:92)“ lokasi adalah keputusan yang dibuat perusahaan atau instansi pendidikan berkaitan dengan di mana operasi dan stafnya akan ditempatkan". Lokasi usaha yaitu saluran distribusi perusahaan karena lokasi berhubungan langsung dengan pembeli atau konsumen dengan kata lain lokasi tersebut tempat produsen menyalurkan produk kepada konsumen komitmen sumber daya jangka panjang. Lokasi akan mempengaruhi pertumbuhan serta pendapat pada pemahaman penulis bahwa lokasi adalah suatu keputusan perusahaan untuk menentukan tempat usaha menjalankan kegiatan usaha ataupun kegiatan 
operasional serta mendistribusikan barang atau jasa yang menjadi kegiatan bisnis kepada para konsumen.

\subsection{Promosi}

Menurut Tjiptono (2015 : 387) promosi merupakan bauran pemasaran yang berusaha menjelaskan,mengambil hati dan memperingatkan konsumen akan merek dan produk dari suatu perusahaan. Promosi merupakan variabel dalam bauran pemasaran yang benar - benar penting dilaksanakan oleh perusahaan dalam mempromosikan produk dan jasa. Buchari Alma ( 2013 : 181) promosi adalah hubungan yang membantu menjelasankan atau meyakinkan calon konsumen berhubungan barang dan jasa serta aktivitas promosi bukan hanya berperan sebagai alat komunikasi antara perusahaan dengan konsumen tetapi juga untuk mempengaruhi konsumen dalam aktivitas pembelian dan penggunaan jasadengan harapan serta keinginan.

Buchari Alma ( 2013 : 181 ) menyatakan promosi adalah komunikasi yang memberi penjelasan meyakinkan calon konsumen tentang barang dan jasa serta kegiatan promosi bukan hanya berfungsi sebagai alat komunikasi antara perusahaan dengan konsumen melainkan juga untuk mempengaruhi konsumen dalam kegiatan pembelian dan penggunaan jasa dengan keinginan serta kebutuhannya. promosi merupakan kegiatan menginformasikan suatu produk atau jasa yang ditawarkan dengan tujuan yang menarik calon konsumen agar membeli dan mengkonsumsinya. Salah satu untuk membantu perusahaan dalam mengadakan komunikasi dengan konsumen yaitu dengan promosi dapat disampaikan informasi berupa pengetahuan mengenai produk yang ditawarkan.

\subsection{Keputusan pembelian}

Keputusan pembelian adalah tindakan konsumen untuk membeli suatu produk barang ataupun jasa. "Customer buyer behavior refers to the buying behavior of final consumers-individuals and households that buy goods and services for personal consumption" Menurut Kotler dan Amstrong ( 2014 : 158 )'”.Menurut Peter - Olson dalam Mulyadi Nitisusastro (2012:195) keputusan pembelian merupakan metode korelasi dengan sikap afektif, sikap kognitif dan sikap behavior dengan faktor latar belakang dan manusia dalam melakukan pergantian semua perspektif kehidupan. Sikap kognitif merefleksikan sikap - sikap pemahaman sikap afeketif mempertimbangkan sikap keteguhan dan perilaku mempertimbangkan sikap kegiatan nyata.

Keputusan dalam pembelian adalah bagian dari unsur yang melekat pada individu yang disebut behavior serta merujuk pada tindakan fisik yang nyata dan dapat dilihat ataupun diukur oleh orang lain. Keputusan pembelian tidak dapat terpisahkan dari bagaimana sifat seorang konsumen ( consumer behavior ) sehingga masing - masing konsumen memiliki kebiasaan yang berbeda dalam melakukan pembelian.

\subsection{Penelitian Terdahulu}

1. Pengenggar dan Wahyu (2016) mengkajikualitas pelayanan, lokasi, fasilitas dan keputusan pembelianhasil pengkajian ini menunjukan secara parsial berdampak positif dan signifikan antara kualitas pelayanan, lokasidan fasilitas serta mengunakan Teknik pengambilan sampel dalam pengkajian ini menggunakan non probability sampling dan sama - sama menggunakan uji coba korelasi, uji coba determinasi, uji coba regresi linear sederhana berganda dan uji coba signifikasi”.

2. Kartini (2016) mengkajipromosi berdampak signifikan terhadap keputusan pembelian berdasarkan percobaan secara parsial yang membuktikan bahwa promosi berdampak positif dan signifikan terhadap keputusan pembelian dengan sama - sama menggunakan uji coba korelasi, uji coba determinasi, uji coba regresi linear sederhana berganda dan uji coba signifikasi”. 
3. Linda dan Asmina (2017) mengkaji bahwaSama - sama menggunakan uji coba korelasi, uji coba determinasi, uji coba regresi linear sederhana berganda dan uji coba signifikasi

\subsection{Kerangka Pemikiran}

Dari beberapa dasar teori yang ada serta dari penelitian sebelumnya maka berikut ini adalah kerangka pemikir penelitian :

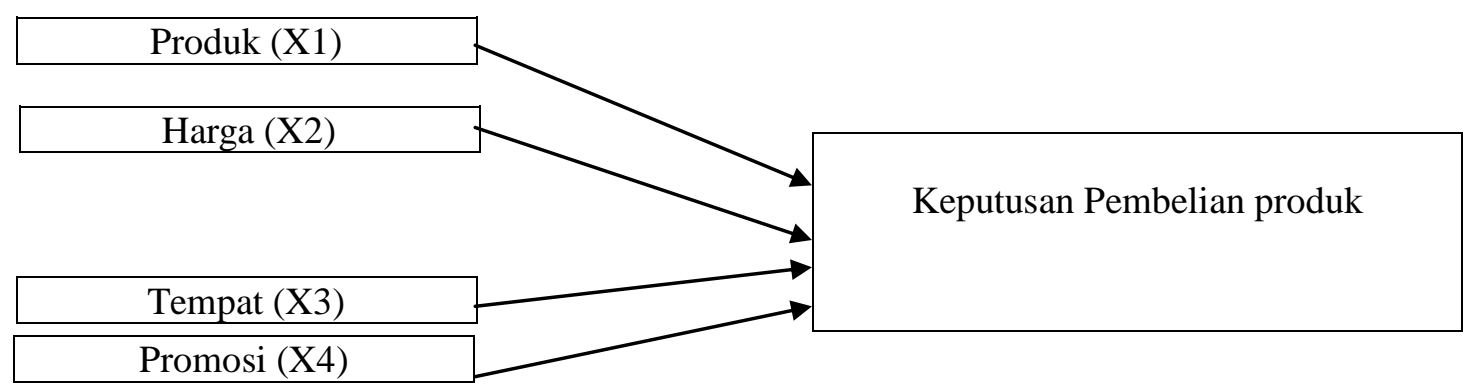

Gambar 2.1

sumber : diolah sendiri.

1. Variabel Bebas $(\mathrm{X})$

Yaitu Harga (X1), Produk (X2), Promosi (X3), Tempat(X4).

2. Variabel terikat $(\mathrm{Y})$

Yaitu keputusan pembelian produk.

\subsection{PENGEMBANGAN HIPOTESIS PENELITIAN}

Hipotesis adalah jawaban atas masalah dalam penelitian dan pernyataan tentang pengaruh hubungan dua variabel atau lebih.

2.10.1 Pengaruh Produk dengan Keputusan Pembelian

Kotler dan Armstrong oleh T.Hermaya ( 2012 : 347 ) Kualitas produk adalah kemampuan suatu produk untuk melakukan fungsi - fungsinya yang meliputi daya tahan, keandalan, ketepatan, kemudahan, operasi dan perbaikan serta atribut lainnya Jika perusahaan ingin berkembang apa lagi harus meraih keuntungan mereka tidak lagi punya pilihan selain mengadopsi konsep kualitas. Ini menunjukkan bahwa kualitas mempunyai pengaruh terhadap konsumen. Konsumen tentunya tidak akan membeli produk yang tidak bisa memenuhi harapannya, Semakin berkualitas suatu produk maka semakin tinggi keputusan konsumen untuk melakukan pembelian. Harga merupakan jumlah uang (kemungkinan ditambah beberapa barang) yang dibutuhkan untuk memperoleh beberapa kombinasi sebuah produk dan pelayanan yang menyertainya. Hal ini dapat dibuktikan oleh penelitan sebelumnya meneliti hubungan antara kualitas produk dengan keputusan pembelian demikian,hipotesis yang dirumuskan adalah :

\section{H1 : Produk berpengaruh terhadap Keputusan Pembelian}

\subsubsection{Pengaruh Harga dengan Keputusan Pembelian}

Harga adalah nilai barang dinyatakan dengan uang ( Alma, 2011 : 169 ). Harga yang ditetapkan harus dapat menutup semua ongkos, atau bahkan lebih dari itu, yaitu untuk mendapatkan laba. Tetapi jika harga ditentukan terlalu tinggi akan berakibat kurang menguntungkan. Penentuan harga merupakan salah satu keputusan 
yang penting bagi manajemen Dalam hal ini pembeli akan berkurang, volume penjualan berkurang semua biaya mungkin tidak dapat ditutup dan akhirnya perusahaan akan menderita rugi. Salah satu prinsip bagi manajemen dalam penentuan harga adalah menitikberatkan pada kemauan pembeli untuk harga yang telah ditentukan dengan jumlah yang cukup untuk menutup ongkos - ongkos dan menghasilkan laba Harga dapat mempengaruhi keputusan pembelian. Hasil penelitian menyatakan bahwa harga berpengaruh terhadap keputusan pembelian demikian hipotesis yang dirumuskan adalah sebagai berikut :

H2 : Harga berpengaruh terhadap Keputusan Pembelian

\subsubsection{Pengaruh Lokasi dengan Keputusan Pembelian}

Lokasi merupakan suatu tempat dimana hasil produk perusahaan berada. Menurut Tjiptono ( 2015 : 345 ) Lokasi akan ikut berperan dalam menentukan kesuksesan suatu usaha karena lokasi akan berpengaruh terhadap besarnya pasar potensial yang dapat dicapai oleh suatu perusahaan. Pemilihan tempat perlu mempertimbangkan berbagai faktor berikut misalnya Akses lokasi yang mudah dijangkau oleh sarana transportasi umum dan visibilitas yaitu lokasi yang dapat terlihat dengan jelas berada di tepi jalan serta berpengaruh terhadap keputusan pembelian. demikian hipotesis yang dirumuskan adalah :

\section{H3 : Lokasi berpengaruh terhadap Keputusan Pembelian}

\subsubsection{Pengaruh Promosi dengan Keputusan Pembelian}

Menurut Tjiptono ( $2015: 387$ ) promosi merupakan bauran pemasaran yang berupaya menginformasikan, membujuk dan mengingatkan kembali konsumen dengan merek dan produk perusahaan. Promosi merupakan salah satu variabel marketing mix yang memiliki peran penting bagi perusahaan dalam upaya memasarkan produk atau jasanya. Promosi diharapkan dapat menarik minat konsumen untuk membeli produk yang ditawarkan perusahaan. seorang pemasar ( marketer ) harus memahami karakteristik - karakteristik yang terdapat pada alat promosi agar dapat menggunakannya secara efektif dan efisien bahwa Promosi berpengaruh terhadap keputusan pembelian. demikian hipotesis yang dirumuskan adalah :

\section{H4: Promosi berpengaruh terhadap Keputusan Pembelian}

\section{Metode Penelitian}

Penelitian ini menggunakan penelitian kuantitatif yakni yang datanya berupa bilangan dan analisis menggunakan statistik. Data yang diterima dari hasil survei yaitu berupa informasi yang dikumpulkan dari responden. Dalam analisis ini pencarian terhadap keputusan pembelian konsumen menggunakan metode survei yang dilakukan di Tahu Dadi Jaya di Boyolali, dan instrumen utama yang digunakan yaitu dengan kuesioner. "Teknik pengumpulan data melalui survei ini sangat strategis, dimana penelitian dilakukan dalam ruang alamiah atau bukan buatan dan penelitian melakukan perlakuan dalam pengumpulan data. Sugiyono ( $2011: 6$ )". Variabel terikat adalah variabel yang akan berdampak menjadi akibat karena adanya variabel bebas. Analisis Deskriptif yaitu kajian yang merumuskan pada variabel promosi, harga, produk dan tempat yang berpengaruh terhadap keputusan pembelian produk Tahu Dadi Jaya. Analisis regresi liner berganda pada variabel tersebut berpengaruh terhadap keputusan pembelian Tahu Dadi Jaya.

Dari hasil penelitian yang dikumpulkan maka selanjutnya akan dapat disajikan metode analisis sebagai berikut :

1. Analisis Deskriptif yaitu analisis yang menguraikan variabel produk, harga, lokasi dan promosi terhadap keputusan pembelian produk Tahu Dadi Jaya di Boyolali. 
2. Analisis Regresi Berganda yaitu analisis yang mempengaruh variabel produk, harga, lokasi dan promosi terhadap keputusan pembelian produk Tahu Dadi Jaya di Boyolali.

\subsection{Uji Hipotesis}

\subsection{Uji Signifikan Parsial (Uji -t)}

Pengujian ini dilakukan untuk mengetahui pengaruh suatu variabel independen secara parsial (individual) terhadap variabel dependen. kriteria pengujian artinya secara parsial tidak terdapat pengaruh yang positif dan signifikan dari variabel independen $\left(\mathrm{X}_{1}, \mathrm{X}_{2}, \mathrm{X}_{3}, \mathrm{X}_{4}\right)$ terhadap variabel dependen ( $\mathrm{Y}$ )

Kriteria pengujiannya adalah:

H0: $X_{1}, X_{2}, X_{3}, X_{4}=0$, berarti secara parsial tidak pengaruh positif dan signifikan dari variabel independen terhadap variabel dependen.

H0: $\mathrm{X}_{1}, \mathrm{X}_{2}, \mathrm{X}_{3}, \mathrm{X}_{4} \neq 0$, berarti secara parsial berpengaruh positif dan signifikan dari variabel independen terhadap variabel dependen.

Kriteria pengambilan keputusannya adalah:

$\mathrm{H}_{0}$ diterima, jika $\mathrm{t}_{\text {hitung }}<\mathrm{t}$ tabel pada $\alpha=5 \% \mathrm{H}_{1}$ ditolak, jika $\mathrm{t}$ hitung $>\mathrm{t}$ tabel pada $\alpha=$ $5 \%$

\subsection{Uji Signifikan Simulta n (Uji- F)}

Pengujian ini dilakukan mengetahui apakah semua variabel bebas dimasukkan kedalam model tersebut mempunyai pengaruh yang secara bersama - sama terhadap variabel terikat.

Kriteria pengujiannya adalah:

H0: $b_{1}, b_{2}, b_{3}, b_{4}=0$, berarti secara simultan tidak berpengaruh yang positif dan signifikan dari variabel independen terhadap variabel dependen.

H0: $b_{1}, b_{2}, b_{3}, b_{4} \neq 0$, berarti secara simultan berpengaruh yang positif dan signifikan dari variabel independen terhadap variabel dependen.

Kriteria pengambilan keputusan adalah:

$\mathrm{H}_{0}$ diterima, jika $\mathrm{F}_{\text {hitung }}<\mathrm{F}_{\text {tabel }}$ pada $\alpha=5 \% \mathrm{H}_{1}$ ditolak jika $\mathrm{F}_{\text {hitung }}>\mathrm{F}_{\text {tabel }}$ pada $\alpha=5 \%$

\subsection{Koefisien Determinasi $\left(\mathbf{R}^{2}\right)$}

Koefisien determinasi ( $\mathrm{R}^{2}$ ) adalah mengukur kemampuan suatu model dalam menerangkan variable dependen. Nilai koefisien determinasi adalah antara nol dan satu. Nilai $\mathrm{R}^{2}$ mendekati satu berarti variabel - variabel independen memberikan semua informasi yang dibutuhkan untuk memprediksi variabel dependen. Kelemahan yang mendasar penggunaan $\mathrm{R}^{2}$ adalah biasanya jumlah variabel independen yang dimasukkan ke dala suatu model. Setiap penambahan variabel dalam model maka $\mathrm{R}^{2}$ pasti akan meningkat tanpa peduli variabel independen tersebut berpengaruh secara signifikan atau tidak. Maka sebaiknya menggunakan nilai adjusted $\mathrm{R}^{2}$ untuk mengevaluasi model regresi yang terbaik (Ghozali, 2011:87). 


\subsection{Teknik Pengujian Data}

\subsubsection{Uji validitas}

Uji intrumen penelitian meliputi uji validitas dan reliabilitas. Validitas berkaitan denga persoalan untuk membatasi atau menekan kesalahan - kesalahan dalam penelitian, sehingga hasil yang diperoleh akurat dan berguna untuk dilakukan. Uji validitas menunjukkan sejauh mana relevansi pernyataan terhadap apa yang dinyatakan atau yang ingin diukur dalam penelitian, sedangkan uji reliabilitas untuk menunjukka $\mathrm{n}$ sejauh mana tingkat konsistenan pengukuran dari satu responden ke responden yang lain dengan kata lain sejauh mana pernyataan dapat dipahami sehingga tidak menyebabkan beda interpretasi dalam pemahaman pernyataan tersebut. Pengujian validitas dilakukan dengan cara mengkorelasikan skor masingmasing pernyataan item yang ditujukan kepada responden dengan total skor untuk seluruh item.

Teknik korelasi yang digunakan untuk menguji validitas butir pernyataan adalah korelasi Pearson Product Moment. Apabila nilai koefisien korelasi butir item pernyataan yang sedang di uji lebih besar besar dari 0.300 maka dapat disimpulkan bahwa item pernyataan tersebut merupa kan konstruksi yang valid. Sebaliknya jika nilai koefisien korelasi butir item pernyataan yang sedang di uji lebih kecil dari kritis sebesar 0,300 maka dapat disimpulkan bahwa item pernyataan tersebut merupa kan konstruksi ( construct) yang tidak valid ataupun bisa dikatakan pernyataan tersebut tidak sesuai.

\subsubsection{Uji Reliabilitas}

Pengujian reliabilitas dilakukan terhadap butir pernyataan yang termasuk dalam kategori valid. Pengujian reliabilitas dilakukan dengan cara menguji coba instrumen sekali saja kemudian dianalisis menggunakan metode alphacronbach. Kuesioner dikatakan andal apabila koefisien reliabilitas bernilai positif dan lebih besar dari pada 0,7 Sugiyono ( $2013: 121$ )

\subsubsection{Uji Asumsi Klasik Regresi Berganda}

\section{Uji Normalitas}

Uji normalitas untuk menguji apakah dalam model regresi variabel pengganggu atau residual memiliki distribusi normal. Jika terdapat normalitas maka residual memiliki distribusi normal. Jika terdapat normalitas maka residual akan terdistribusi secara normal dan independen ( Ghozali, 2011 : 173 ). Suatu data dikatakan normal apabila perbedaan antara nilai prediksi dengan skor sesungguhnya atau error terdistribusi secara simetri disekitar nilai means sama dengan nol. Normalitas dari suatu variabel dapat dideteksi dengan grafik atau uji statistik.Normalitas data dapat terlihat dari plotgrafik histogram. Jika garis yang menggambarkan data sesungguhnya mengikuti garis diagonalnya maka data tersebut dinyatakan normal.

\section{Uji Multikolonieritas}

Multikolinearitas merupakan hubungan linier yang sempurna antara semua variabel bebas. Uji multikolonieritas bertujuan untuk menguji apakah model regresi ditemukan adanya korelasi antara variabel bebas atau independen (Ghozali, 2011 : 105 ). Multikolonieritas dapat dilihat dari nilai tolerance dan lawannya variance inf lation factor ( VIF ). Apabila nilai tolerance atau VIF $>0,10$ atau sama dengan nilai VIF $<0,10$ Maka dapat disimpulkan bahwa tidak ada multikolonieritas antara variable independen dalam model regresi pada penelitian ini ( Ghozali, $2011: 106$ ).

\section{Uji Autokorelasi}


Uji Autokorelasi digunakan mengetahui ada tidaknya penyimpangan asumsi klasik. Prasyarat yang dipenuhi tidak adanya autokorelasi dalam model regresi. Metode pengujian yang digunakan adalah dengan uji Durbin-Watson ( Uji DW ) dengan ketentuan sebagai berikut :

1) Jika d lebih kecil dari dL atau lebih besar dari ( 4 - dL ) maka hipotesis nol ditolak yang berarti terdapat autokorelasi.

2) Jika d terletak antara dU dan ( 4 - dU ) maka hipotesis nol diterima yang berarti tidak ada autokorelasi.

3) Jika d terletak antara dL dan dU atau antara ( 4 - Du ) dan ( 4 - dL ) maka tidak menghasilkan kesimpulan yang pasti. Nilai dU dan dL diperoleh dari tabel statistik Durbin Watson yang bergantung banyaknya observasi dan banyaknya variabel yang menjelaskan.

\section{Uji Heteroskedastisitas}

Uji heteroskedastisitas memiliki tujuan menguji apakah dalam model regresi terjadi ketidaksamaan variance dari residual satu pengamatan ke pengamatan yang lain. Apabila variance dari residual datu pengamatan ke pengamatan lain tetap maka disebut dengan Homoskesdastisitas sedangkan jika berbeda maka disebut dengan Heteroskedastisitas. Jika terjadi homoskesdastisitas pada model regresi maka model regresi tersebut baik salah satu cara untuk endeteksi ada atau tidaknya heteroskedastisitas adalah dengan melihat y grafik plot antara nilai prediksi variabel dependen yaitu ZPRED dengan residualnya SRESID. Deteksi ada tidaknya heteroskedastisitas dapat dilakukan dengan melihat ada tidaknya pola titik pada grafik scatteplot antara SRESID dan ZPRED dimana sumbu $\mathrm{Y}$ adalah $\mathrm{Y}$ yang telah diprediksi dan sumbu $\mathrm{X}$ adalah residual ( $\mathrm{Y}$ prediksi $-\mathrm{Y}$ sesungguhnya ) yang telah di studentized menurut Ghozali ( 2011:139).

Dimana dasar analisisnya adalah sebagai berikut :

Jika ada pola tertentu, seperti titik - titik yang ada membentuk pola tertentu yang teratur bergelombang, melebar kemudian menyempit maka mengindikasikan telah terjadi heterokedastisitas.

Jika tidak ada pola yang jelas, serta titik - titik menyebar diatas dan dibawah angka o dan sumbu Y maka tidak terjadi heteroskedastisitas.

\subsection{Teknik Analisa}

Analisis regresi berganda digunakan untuk mengetahui seberapa besar pengaruh variabel - variabel bebas yaitu kualitas produk (X1), Harga kompetitif ( X2 ), promosi (X3 ) dan lokasi (X4) terhadap keputusan pembelian Tahu. Adapan bentuk persamaan regresi linier berganda yang digunakan pada penelitian ini adalah

$Y=a+b_{1} \cdot X_{1}+b_{2} \cdot x_{2}+b_{3} \cdot x_{3}+b_{4} \cdot x_{4}+e$

\section{Dimana :}

$\mathrm{X}_{1}=$ Produk

$\mathrm{X}_{2}=$ Harga

$\mathrm{X}_{3}=$ Promosi

$\mathrm{X}_{4}=$ Lokasi

$\mathrm{Y}=$ Keputusan pembelian konsumen 


$$
\begin{aligned}
& b_{1}=\text { Koefisien regresi produk } \\
& b_{2}=\text { Koefisien regresi harga } \\
& b_{3}=\text { Koefisien regresi lokasi } \\
& b_{4}=\text { Koefisienregresipromosi } \\
& e=\text { eror }
\end{aligned}
$$

\section{Hasil dan Pembahasan}

Berdasarkan data dari 100 responden konsumen Tahu Dadi Jaya di Boyolali. melalui daftar pernyataan didapat kondisi responden tentang nama, alamat, jenis kelamin dan usia. Penggolongan yang dilakukan responden penelitian ini bertujuan untuk mengetahui secara jelas mengenai gambaran responden sebagai objek penelitian.

Hasil analisis data menghasilkan nilai - nilai yang digunakan untuk membuktikan hipotesis dari penelitian yaitu sebagai berikut :

a. Pengaru Produk Terhadap Keputusan Pembelian.

Berdasarkan tabel diatas jika nilai signifikan variabel produk sebesar 0,295>0,05 maka perihal ini membuktikan bahwa produk tidak mempengaruhi secara signifikan terhadap keputusan pembelian.

b. Pengaru Harga Terhadap Keputusan Pembelian.

Berdasarkan tabel diatas diketahui nilai signifikan variabel hargasebesar 0,022<0,05 maka perihal ini membuktikan bahwa harga mempengaruhi secara signifikan terhadap keputusan pembelian.

c. Pengaru Tempat Terhadap Keputusan Pembelian.

Berdasarkan tabel diatas diketahui nilai signifikan variabel tempat sebesar 0,295<0,05 maka perihal ini membuktikan bahwa tempat tidak mempengaruhi secara signifikan terhadap keputusan pembelian.

d. Pengaruh Promosi Terhadap Keputusan Pembelian.

Berdasarkan tabel diatas diketahui nilai signifikan variabel promosi sebesar 0,364 >0,05 maka perihal ini membuktikan bahwa promosi secara parsial tidak berpengaruh terhadap keputusan pembelian.

\section{Kesimpulan}

1. Berdasarkan hasil analisis regresi berganda dengan uji $\mathrm{F}$ bahwa sig. 0,004 $<0,05$ berarti bahwa semua variabel berpengaruh secara simultan terhadap keputusan pembelian Tahu Dadi Jaya di Boyolali.

2. Berdasarkan hasil analisis regresi berganda dengan uji t bahwa produk, jika sig. 0,295 >0,05 maka perihal ini membuktikan bahwa variabel produk secara parsial tidak mempengaruhisignifikan terhadap keputusan pembelian.

3. Berdasarkan hasil analisis regresi berganda dengan uji $\mathrm{t}$ bahwa harga, jika sig. 0,022 >0,05 maka perihal ini membuktikan bahwa variabel harga secara parsial mempengaruhi signifikan terhadap keputusan pembelian.

4. Berdasarkan hasil analisis regresi berganda dengan uji t bahwa tempat, jika sig. 0,295 >0,05 maka perihal ini membuktikan bahwa variabel tempat secara parsial tidak mempengaruhi signifikan terhadap keputusan pembelian. 
5. Berdasarkan hasil analisis regresi berganda dengan uji t bahwa promosi, jika sig. 0,364 >0,05 maka perihal ini membuktikan bahwa variabel promosi secara parsial tidak mempengaruhi signifikan terhadap keputusan pembelian.

\section{DAFTAR PUSTAKA}

Aji,J. M. M.\& Supriono, A. (2016)“Faktor-Faktor yang Mempengaruhi Perilaku Konsumen dalam Pembelian Produk Tahu di Kabupaten Jember". Jurnal Pamator: Jurnal Ilmiah Universitas Trunojoyo, 9(1)".

Asshiddieqi, F., \& MUDIANTONO, M. (2012). "Analisis Pengaruh Harga, Desain Produk, Dan Citra Merek Terhadap Keputusan Pembelian (Studi Kasus Pada Produk Crooz Di Distro Ultraa Store Semarang) (Doctoral dissertation, Fakultas Ekonomika dan Bisnis)". Alfabeta.

Buchari, A. (2011). "Manajemen pemasaran dan pemasaran jasa". Bandung:

Dharmmesta, B. S., \& Handoko, T. H. (2011). "Manajemen Pemasaran Analisis Perilaku Konsumen (Edisi 1)". Yogyakarta: BPFE".

Harfin, F. P. (2018). "Pengaruh produk, harga, tempat, dan promosi terhadap kepuasan konsumen rambak ceker ayam" 99" UD. snack krezz (Doctoral dissertation, Wijaya Kusuma Surabaya University)".

Kamaru, T., \& Kurniati, A. (2017). "Dampak Harga Dan Kualitas Pelayanan Terhadap Kepuasan Pelanggan Dampaknya Pada Loyalitas Pelanggan Usaha Kecil Menengah Monster Shaker Café”. JURNAL MANAJEMEN FE-UB, 5(2).

Kristi, E. D. (2018) "Analisis faktor-faktor yang mempengaruhi konsumen dalam mengambil keputusan pembelian ulang jasa transportasi berbasis aplikasi taksi online uber di daerah Surabaya dan sekitarnya" (Doctoral dissertation, Wijaya Kusuma Surabaya University)". 